\title{
PROTECTING THE MARGINALISED: THE ROLE OF THE EUROPEAN CONVENTION ON HUMAN RIGHTS
}

\author{
Colin Harvey, Professor of Constitutional and Human Rights Law, \\ Department of Law, University of Leeds and Stephen Livingstone \\ Professor of Human Rights Law, Centre for International and \\ Comparative Human Rights Law, Queen's University Belfast
}

\section{INTRODUCTION}

The European Court of Human Rights has played a significant role in the protection of human rights in Europe. Over the years it has demonstrated a willingness to develop the Convention in a way intended to make rights both practical and effective. While it has not always succeeded in this task, and has shown caution in some areas, it has made an important contribution by developing a rich human rights jurisprudence. The Court's dynamic approach has helped to give the Convention the public profile that it now has across Europe. Those struggling to protect human rights are more likely to make use of the Convention if it is seen to work. In the United Kingdom (UK) the rise of "Strasbourg-style" judicial reasoning may be one practical impact of the Human Rights Act 1998. As is consistently stated, judicial decision-making in the human rights sphere is not an end in itself. The ultimate objective is more effective human rights protection for those individuals and groups which require it. The aim of this article is to explore the contribution which the Court has made in protecting the rights of immigrants, asylum seekers and prisoners.

The Court has, as noted, made a contribution to the creation of a rich human rights jurisprudence. Doctrinal development does not necessarily make a difference in practice, but the crafting of this case law has had an impact and is of importance. As we argue in this article the Court's work is not without problems. It has tended to opt for a cautious and incremental approach to the development of the Convention. On some rights it has failed to provide a coherent justification of its own jurisprudence. The Court is an institutional actor operating in a European political and legal context. It does not function in a political vacuum. The judges are evidently conscious of this wider political context. While there are sound reasons why judges should be alert to this, we argue that this must not shade into excessive empathy for the difficulties faced by states. The European Court of Human Rights should function with its own paradigmatic understanding of the judicial role tied to the core values of the Convention system. There is a strong justification for a robust approach to the rights of the groups discussed in this article. If the Court is concerned with strengthening democracy and human rights protection, then it should take a clear stand with reference to those groups silenced within the democratic process. We suggest that the plight of immigrants, asylum seekers and prisoners in Europe demands a coherent and assertive response. The Court can assist in the struggle to protect these marginalised groups and bring their voices more fully within the public sphere of member states of the Council of Europe. 


\section{HUMAN RIGHTS AND JUDICIAL ACTIVISM: THE LAW AND POLITICS OF INTERPRETATION}

It is often suggested that human rights law demands a purposive approach to interpretation. This is because it is difficult to conceive of, for example, the rights contained in a human rights treaty as purely contractual. When states sign and ratify a human rights treaty they are granting rights to individuals and not purely reaching an inter-state agreement. The customary international law rules of treaty interpretation are reflected in the Vienna Convention on the Law of Treaties 1969. ${ }^{1}$ There reference can be found to a mixture of interpretative methods, including the contextual and purposive. In practice the European Court of Human Rights has focused on the object and purpose of the Convention and applied a dynamic approach to its provisions. ${ }^{2}$ On occasion it is suggested that the Convention has a special constitutional status and this argument reinforces the legitimacy of the evolutive approach adopted. This approach to interpretation leaves room for a tension to emerge later if, for example, a monitoring body or court adopts an interpretation of the instrument which departs radically from the one state parties thought they had signed up to. The success of an international instrument can, however, be dependent on whether an institution is created which has an interest in its dynamic interpretation. One of the reasons why the European Convention has been so successful is precisely because institutions were created to give authoritative meaning to the rights it contains. While cautious in some areas, the Court has not been afraid of pushing at the boundaries of Convention rights in others. This is if we assume that there are boundaries contained within the abstract language of the Convention. It might be more accurate to argue that the Court has shaped its own boundaries, and there are very few natural limits to some Convention rights. What this alerts us to is the role of judicial activism in shaping the development of European human rights law. All the old and familiar controversies are raised by this, surrounding the legitimacy of the judicial role. In human rights law the context for this discussion is changing. If in the past there was a tendency to rely excessively on judicial activism this is no longer the case today. One clear example of this is the recent rise in interest in national institutions for the protection of human rights. ${ }^{3}$ At least one of the reasons for their establishment is scepticism about the role of national courts. ${ }^{4}$ There is in addition more sophisticated thinking about how human rights might be mainstreamed in domestic contexts. This re-focuses attention on the fact that it is to the national level that we must still look for effective human rights protection. In making use of a purposive approach the European Court of Human Rights is ultimately fulfilling its task of facilitating national level protection. The problems surrounding this arise most starkly in the deployment of the margin of appreciation doctrine. This

Articles 31-33.

See, for example, Golder v UK (1979-1980) 22 EHRR 524.

${ }^{3}$ See Principles relating to the status of National Institutions (Paris Principles), UNGA Res 48/134, 20 December 1993; S. Spencer and I. Bynoe A Human Rights Commission: The Options for Britain and Northern Ireland (1998).

4 A. Gallagher "Making human rights treaty obligations a reality: Working with new actors and partners" in P. Alston and J. Crawford (eds) The Future of UN Human Rights Treaty Monitoring (2000) pp 201-227. 
can be portrayed as either a welcome openness to national diversity or as timid capitulation to cultural relativism. ${ }^{5}$ Mahoney states:

"As in any system of international enforcement of human
rights, some interpretational tool is needed to draw the line
between what is properly a matter for each community to
decide at local level and what is so fundamental that it entails
the same requirement for all countries whatever the variations
in traditions and culture. In the European system that function
is served by the doctrine of the margin of appreciation".

As he also notes, the doctrine has attracted severe criticism from those who believe it encourages excessive deference to local traditions and practices. Mahoney, nevertheless, defends it as a legitimate principle of interpretation. Why? He does so because he believes that the Convention is grounded in a particular version of political philosophy. ${ }^{7}$ The political theory is that "political democracy is the best system of government for ensuring respect of fundamental freedoms and human rights". ${ }^{8}$ What is noteworthy in this argument is the view of the Court as a participant in a transnational dialogue about the regulation of social, economic, political and cultural life. This role demands limits and restraint as well as activism. Restraint may, of course, be motivated by policy factors just as much as any principled basis in notions of political democracy. Whatever the motivation, activism may be particularly suited to protecting the rights of those individuals and groups systematically neglected by the democratic process. This clearly applies to the groups examined in this article. Political democracy has not always demonstrated sufficient concern and respect for all individuals and groups. The dynamic approach of the Court can assist in making political democracy work.

The arguments over the margin of appreciation doctrine reveal other problems. The main one is a tendency to overestimate the judicial role in the protection of human rights, to the detriment of all the other mechanisms that currently exist. There is a tendancy to place the judges on a pedestal and then bemoan the fact that they do not reach the desired results. While judges of the European Court should not abdicate responsibility, respectful deference to national level decision-making need not be as problematic as is sometimes suggested. The human rights movement should be careful about placing excessive faith in the judiciary. The reason for introducing these thoughts here is that too often minorities are used unreflectively simply as convenient vehicles to justify judicial activism. While this is understandable we believe that it is important to ground this approach more effectively. Our argument is that the dynamic approach to the protection of rights can be reconciled with a commitment to political democracy. In this way an

5 See P. Mahoney "Marvellous Richness of Diversity or Invidious Cultural Relativism?" (1998) 19 HRLJ 1. See also P. Mahoney "Judicial Activism and Judicial Self-Restraint in the European Court of Human Rights: Two Sides of the Same Coin" (1990) 11 HRLJ 57.

6 Mahoney (1998) ibid. p 1.

7 Ibid. p 3.

8 Ibid. p 3. 
assertive approach by the European Court of Human Rights can enrich and not necessarily undermine political democracy.

There is one final point to note here. Judgments of the Court are influential beyond Europe. Several significant judgments of the Court have attracted attention in other international fora. The Court's jurisprudence has an impact beyond the European context. Slaughter has suggested the term "transjudicial communication" to refer to the fact that courts are in dialogue with one another. ${ }^{9}$ There is a transnational judicial conversation about the meaning of human rights which the Court has made a significant contribution towards. The Court thus has a impact at the national level, but also a less tangible international influence on the development of a transnational dialogue on human rights. This transnational communication is not confined to courts, but that is the specific subject of this article.

While we can argue about the legitimacy of its role, from a results-driven perspective the jurisprudence of the Court has a wide-ranging impact on rights protection. What we have sought to do here is argue that the Court, through a dynamic approach, can make a vital contribution to enriching political democracy, in particular, by ensuring that those groups silenced within democratic life are accorded due concern and respect.

\section{PRISONERS}

Few are more silenced, at least as regards official political discourse, than prisoners. They are a classic "discrete and insular minority", ${ }_{10}^{10}$ who in some member states are denied even the right to vote when in prison. However the European Court of Human Rights has recognised that although prisoners are generally out of sight they should not be out of mind. Starting with the decision in the Golder case in 1975 the Court has rejected the idea that there are any "inherent limitations" on the rights of an individual simply because they are detained in a prison." Instead it has been prepared to review claims emanating from prisons as to the extent to which aspects of prison regimes infringe the rights of those detained within them. As a result the Court and Commission have delivered a significant range of rulings on matters such as prisoners' correspondence, disciplinary procedures, decision-making with respect to release and the conditions within which prisoners are held. Many of these have wrought significant change in national practices in respect of imprisonment, notably in the UK from which a substantial proportion of cases have originated.

Engaging with prisons though poses some significant dilemmas for a human rights tribunal. Taken literally it is difficult to see how any prison regime can conform with notions of respect for private and family life, freedom of expression and even the prohibition on inhuman and degrading treatment. Even the most humane regime of imprisonment involves removing people from regular contact with their family, depriving them almost entirely of

9 A. M. Slaughter "A Typology of Transjudicial Communication" (1994) 29 University of Richmond Law Review 100.

10 The words of Stone J in United States v Carolene Products (1938) 304 US 144, 152-3 n. 4.

11 Golder v United Kingdom (1975) 1 EHRR 524. 
privacy, curtailing their freedom of movement and denying them the possibility of voluntarily associating with others. Yet the European Convention on Human Rights was clearly not intended to prohibit imprisonment in Council of Europe member states. Article 5(1)(a) provides for the "lawful detention of a person after conviction by a competent court" as one of the permitted deprivations of the right to liberty, and those who drafted the Convention clearly envisaged that imprisonment would be available as a penalty for those convicted of criminal offences. Indeed with the progressive elimination of the use of the death penalty which is facilitated by Protocol 6 and encouraged by the Committee of Ministers, imprisonment has been recognised as the only penalty which is permitted (perhaps even required under some interpretations of recent Article 13 jurisprudence) for serious criminal offences. Indeed the evidence in most Council of Europe states in the last decade is that the use of imprisonment is substantially on the increase. ${ }^{12}$

The Strasbourg institutions thus face a tension. On the one hand they recognise that the notions of individual rights contained in the Convention extend to all persons who find themselves within a Convention member state. On the other hand those same states clearly take the view that the operation of a prison system is consistent with their being parties to international human rights provisions such as the ECHR. The jurisprudence on prisons issues very much reflects this tension. In some areas it has been highly interventionist, calling into question long established practices of prison management, in others it has been characterised by a reluctance to intervene and rather brusque dismissals of an applicant's claims. If an overall theme can be discerned it is perhaps that the Court and Commission have been more willing to uphold lawyer's values of fair procedures (especially in respect of access to court and a fair hearing) than intervene on matters of substance. This perhaps reflects a deeper view that while issues of sentencing and the management of prisons lie primarily within the discretion of the state the Court will be prepared to intervene if prisons become islands of lawlessness, spaces where capricious brutality is allowed to flourish and where few other forms of external scrutiny or redress exist.

\section{Areas of Intervention: Communications, Discipline and Violence in Prisons}

The Golder case itself concerned restrictions on prisoners' correspondence and it is perhaps in this area that the Strasbourg case has shown itself most willing to intervene. In Golder English prison practices which prohibited a prisoner from contacting his solicitor before any complaint had first been resolved internally within the prison were held to contravene both the Article 6 right of access to the courts and the Article 8 right of privacy in correspondence. The Court stressed especially the importance of allowing a prisoner unrestrained access to a lawyer in order that they might vindicate the rights which they retained despite their imprisonment. This was a theme the Court returned to in its 1992 decision in Campbell v United Kingdom, when it found a breach of Article 8 where a Scottish prisoner's letters to his 
lawyer were regularly read by the prison authorities. ${ }^{13}$ Again stressing the importance of ensuring that prisoners are able to have unhindered access to the courts an 8 to 1 majority in Strasbourg indicated that only in exceptional circumstances, for example where the authorities have reason to believe the privilege is being abused, could prisoners' letters be read or stopped. ${ }^{14}$ These decisions have had a significant impact on prison regulations within the United Kingdom ${ }^{15}$ and the Court has also given rulings on the impermissibility of restrictions on correspondence with lawyers in respect of a number of other member states. ${ }^{16}$

The willingness to intervene in respect of correspondence has not been limited to correspondence with lawyers. Although the practice of censoring a prisoner's correspondence has been recognised as not being a breach of the Convention per se ${ }^{17}$ the Court has been prepared to require some regulation of it. In the Silver case the Court held that English Prison Rules allowing the authorities to stop letters, including those to relatives and MPs, which they found "objectionable", did not meet the standard of ensuring that restrictions on correspondence were "prescribed by law". ${ }^{18}$ A similar view was reached in the Diana case where, although Italian law left the decision to read correspondence to a judge, it again provided little guidance on when letters might be read or stopped. ${ }^{19}$ The Court went on in Silver to indicate that some of the specific grounds for stopping letters actually operated by the prison authorities, for example that they used foul language or were critical of the authorities, could not be justified as "necessary in a democratic society". Once again the result has been significant changes in the way prisoners' correspondence is treated in the United Kingdom. The grounds of censorship have been significantly narrowed and a Standing Order in which they are contained has been published, enabling prisoners to have a better idea of what may or may not be subject to restriction.

Internal prison discipline systems are another area where the Strasbourg system has had an impact. The landmark case here was the Court's 1983 judgment in Campbell and Fell $\mathrm{v}$ United Kingdom. ${ }^{20}$ There the Court concluded that although United Kingdom law categorised proceedings before a prison Board of Visitors as "disciplinary" in character they could be viewed as "criminal" for the purposes of Article 6 of the Convention, primarily because of the severity of the penalty imposed. Under then prevailing rules the Board had the authority to impose unlimited loss of remission and did in fact impose a penalty of 570 days loss of remission on

13 (1993) 15 EHRR 137

14 Similar principles govern the extent to which prison authorities may listen to oral or telephone conversations with lawyers; see $S$ v Switzerland (1992) 14 EHRR 670.

15 See S. Livingstone and T. Owen Prison Law (2 ${ }^{\text {nd }}$ ed, 1999) pp 213-9. Most recently the Court extended this protection to correspondence with a trustee in bankruptcy, Foxley v United Kingdom, unreported 20 June 2000.

16 See, for example, Domenichini v Italy [1997] EHRLR 192, Petra v Romania, unreported 23 September 1998.

17 See Boyle and Rice v United Kingdom (1988) 10 EHRR 425.

18 Silver v United Kingdom (1981) 3 EHRR 475.

19 Diana v Italy, unreported 15 November 1996

${ }^{20}$ (1984) 7 EHRR 165. 
one of the prisoners concerned. To the Strasbourg court a penalty of such severity, effectively meaning that a prisoner would spend over a year and a half longer in prison, was such that it should only be imposed after proceedings which respected the fair trial guarantees appropriate to criminal proceedings. The most immediate impact of the Campbell ruling was that prisoners were entitled to legal representation in at least some internal prison disciplinary proceedings, a constraint which began a series of moves to first reduce the penalties available to Boards of Visitors in the English prison system and then finally to remove their disciplinary powers altogether. ${ }^{21}$ However, by basing the issue of whether prison disciplinary proceedings become "criminal" on the length of penalty awarded rather than the fact that an internal disciplinary tribunal can extend someone's deprivation of liberty at all, the Court left uncertain the extent to which states may retain internal disciplinary proceedings at all. In many Council of Europe member states Prison Directors or Governors will hear disciplinary charges brought against prisoners by prison staff and are able to order penalties if they find the prisoner guilty. Clearly such proceedings cannot comply with the Article $6(1)$ requirement of a hearing before an independent and impartial tribunal but the Convention will only be breached if the applicant can establish that the proceedings relate to "criminal charges" or the determination of "civil rights and obligations". The Commission, in its admissibility decision in Pelle $\mathrm{v}$ France, ${ }^{22}$ concluded that a penalty of 18 days loss of remission did not suffice to trigger the "criminal charge" requirement, but it remains unclear whether 42 days, the current maximum in Northern Ireland, would be treated similarly. An early challenge under the Human Rights Act is likely. If successful it might require the state to introduce a fully independent element into all prison disciplinary proceedings. However one wonders whether this would be entirely desirable since it might be accompanied by a rise again in the potential penalties a tribunal could hand out, coupled with greater formality and delay. As Conor Gearty has pointed out elsewhere it is not always clear that compliance with the formal requirements of the Convention will bring an actual improvement in people's rights. ${ }^{23}$

Prisoners have also benefited from the Court's progressive strengthening of the Article 3 protection against inhuman and degrading treatment, especially where this relates to violence by agents of the state. Although cases such as Tomasi, Ribitsch, Aydin, Assenov and Selmouni have occurred in a police detention context, their principles are equally applicable to the detention of people in prisons. ${ }^{24}$ These include the idea that any use of force against a detainee which is not rendered strictly necessary by their conduct is a breach of Article 3, that the burden is on the state with regard to someone who went

${ }^{21}$ For a summary of these developments see S. Livingstone "The Impact of Judicial Review on Prisons" in B. Hadfield (ed) Judicial Review: A Thematic Approach 1995) pp 167-86. At the time of writing Boards retain a disciplinary role in Northern Ireland, though this is currently under review.

22 (1986) $50 \mathrm{D} \& \mathrm{R} 263$.

${ }^{23}$ See C. Gearty "Terrorism and Human Rights; A Case Study in Impending Legal Realities" (1999) 19 Legal Studies 367, on the "levelling down" of standards to comply with the Human Rights Act.

${ }^{24}$ Tomasi v France Series A No 241-A (1992), Ribitsch v Austria (1995) 21 EHRR 573, Aydin v Turkey (1997) 25 EHRR 251, Assenov v Bulgaria unreported 28 October 1998, Selmouni v France, unreported 28 July 1999 
into custody uninjured but subsequently demonstrates marks or injuries that he has not suffered at the hands of the state, that severe mistreatment of detainees can amount to torture and that the state is under an obligation to conduct an effective investigation of all claims of mistreatment in custody. In the Tekin case the Court applied these principles in finding a breach of Article 3 where there was evidence that a prisoner had been beaten during his detention. ${ }^{25}$ Prisoners may also benefit from the Court's development of the idea that the state has a positive obligation to protect people from death or severe ill-treatment. It has recently admitted the case of Keenan v United Kingdom, which raises questions as to whether the state may breach Article 2 in respect of a young prisoner who commits suicide. ${ }^{26}$

The recent decision of the Grand Chamber in Labita v Italy, however, may suggest that prisoners will face greater evidential difficulties in securing a finding that they were subject to treatment contrary to Article $3{ }^{27}$ Here the applicant claimed that he was subject to regular beatings during his time in prison on remand. He prayed in aid of this claim medical evidence as to broken teeth and knee injuries as well as reports from the judge responsible for overseeing the prison that there was extensive mistreatment and staff lawlessness during the period in question. Eight of the Court felt this was sufficient to justify a finding of a breach of Article 3, especially as the Court unanimously found a breach in respect of inadequate domestic investigation of these complaints and hence that the applicant was hindered in uncovering any more concrete evidence about the incidents. However a narrow majority of 9 of the Court's members felt the applicant had not produced enough specific evidence relating to his specific treatment and in particular noted his failure to complain even to a doctor for over a year. This decision seems somewhat at variance with Tomasi and suggests that, at least in respect of longer periods of imprisonment, the burden of proof remains on the applicant even in relation to proving that treatment of sufficient severity to engage Article 3 has occurred.

\section{Areas of Restraint: Prison Conditions, Informal Discipline and Family Life}

With rising prison populations throughout Europe many of those detained in Council of Europe states find themselves in overcrowded and unhealthy conditions, with little to occupy their time. The European Committee on the Prevention of Torture (ECPT), which draws upon but is not bound by the Court's definition of Article 3, has denounced the conditions in even several western European member states as amounting to inhuman and degrading treatment. $^{28}$ It has only in the past few years turned its attention to the prisons of eastern Europe, where United Nations bodies have already expressed concern about prison environments which are life threatening. However the European Commission and Court of Human Rights have largely proved deaf to any claims that Article 3 has been breached in respect

Tekin v Turkey, unreported 9 June 1998.

26 [1998] EHRLR 648.

27 Unreported, 16 April 2000.

28 See generally R. Morgan and M. Evans Protecting Prisoners: The Standards of the European Committee for the Prevention of Torture in Context (1999). 
of prison conditions. The nadir was arguably reached in Aerts $\mathrm{v}$ Belgium where a majority of the Court found no breach of Article 3 even though the ECPT had already condemned the conditions in the prison in question as inhuman and degrading. ${ }^{29}$ The Court starts from the premise that Article 3 is not meant to prohibit the normal deprivations that result from imprisonment. Since most European prisons have always been overcrowded and unhealthy places the prisoner immediately faces an uphill struggle in demonstrating that the conditions in which they are held amount even to degrading treatment. Commission decisions have indicated that the threshold is fairly high, indicating that three weeks in a cockroach infested cell, for example, did not meet it. ${ }^{30}$ One occasion where the Commission did find conditions amounting to a breach of Article 3 was in the Greek case, where some prisoners were held two to a cell in a very small basement cell for up to nine months, without any recreation and virtually no light. ${ }^{31}$ It may not be entirely coincidental that this finding was made in a case concerning political detainees rather than convicted criminals. The Commission also found that the requisite level of severity to trigger Article 3 was reached in relation to the "dirty protests" in Northern Ireland's jails in the late 1970s. However in the McFeeley case it did not go on to find a breach, arguing that the nature of these conditions were largely the responsibility of the prisoners themselves. ${ }^{32}$

Where complaints have related to specific rather than general conditions, such as solitary confinement, they have fared little better. As Kaufmann has observed: "where measures are imposed for security, disciplinary or protective purposes, the Commission has shown a remarkable tolerance, irrespective of the effects of their stringency and the effects on the health of the victim". ${ }^{33}$ In Krocher and Muller v Switzerland the applicants were detained for several months in cells 8.4 metres square under constant observation via CCTV and in permanently lit cells. ${ }^{34}$ For the first month of this isolation they were denied access to lawyers and families, exercise was limited to 20 minutes a day for the first three months and for six months they were denied access to a TV, radio or newspapers. In concluding that such conditions did not amount to a breach of Article 3 the Commission was clearly influenced by a lack of medical evidence that these conditions amounted to severe suffering and by the fact that the regime was progressively improved.

Some cases raising issues of poor medical treatment in prison have resulted in a finding of a breach of Article $3^{35}$ but the overall impression is that the European Court of Human Rights is reluctant to become too engaged with the issue of prison conditions. In this they may be wary of the fate which befell U.S. Courts, whose extensive involvement with prisons issues in the 1970s and 1980s spawned protracted litigation and a political backlash in the

Unreported, 30 July 1998. The majority focused on the individual applicant and found insufficient medical evidence of his deterioration during his time in custody.

[1969] Yearbook 1.

32 McFeeley v United Kingdom (1981) 3 EHRR 161.

33 P. Kaufmann "Prisoners" in K. Starmer European Human Rights Law (1999) pp 453-91 at $\mathrm{p} 457$.

34 (1982) 34 D \& R 24

35 For example Hurtado v Spain (1994) Series A No 280-A. 
1990s, though not without much good having been done in the opinion of many. ${ }^{36}$ They may also feel that with the creation of the ECPT that the Council of Europe already has an effective mechanism for closely scrutinising detailed issues of prison conditions, even if it does not take a judicial form.

Moving to the issue of informal discipline, such as the use of intra prison transfer, denial of home leave or administrative segregation, there is again little indication of a willingness of the Court or Commission to intervene. Although these measures can often have a significant impact on the quality of a prisoner's life (for example if they are moved further away from where their family live or to a prison where an educational course they were involved in is not available) the Commission has dismissed most applications as not disclosing the engagement of a Convention right. A similar view has been taken of many efforts to raise family life claims, for example in relation to restrictions on the number of visits a prisoner can receive or their initial location. The issue of whether prisoners might be entitled to conjugal visits has also been canvassed without success before the Commission. However some European states now permit this and the Court may yet move to a position where the existence of a "European consensus" on the issue might outweigh the claims of member states to be entitled to a "margin of appreciation" as to how they preserve a prisoner's right to family life.

\section{Release from Prison}

The Strasbourg Court has shown a reluctance to become engaged with issues of sentencing and has generally rejected any claims that sentences are so disproportionate as to amount to an infringement of Article $3{ }^{37}$ However it has displayed a willingness to review procedures at the other end, when a prisoner's release date is not determined automatically by the sentence they received. Again cases from the United Kingdom have been well to the fore in this story, beginning with the Court's decision in Weeks ${ }^{38}$ that prisoners originally sentenced to a discretionary life sentence but who had subsequently been released could not be recalled to prison without the opportunity of having some form of judicial hearing. Three years later, in the case of Thynne, Wilson and Gunnell $\mathrm{v}$ United Kingdom, the Court went further to hold that the lack of an opportunity for discretionary lifers to challenge their continued detention before a court was also a breach of Article 5(4) of the Convention. ${ }^{39}$ More recently the Court has continued this trend in respect of young prisoners sentenced to Her Majesty's Pleasure sentences for murders committed while they were under 18. In the Hussain case the Court took the view that the continued detention of such prisoners should be subject to regular review and that they should have an opportunity

See S. Sturm "The Legacy and Future of Corrections Litigation" (1994) $138 U$ of Pennsylvania LR 639.

37

See Kotalla v Netherlands (1979) 14 D \& R 238, B, H, and L v Austria (1989) 64

$\mathrm{D} \& \mathrm{R} 264$. The nearest it has perhaps got to reviewing a sentence was in Hussain v United Kingdom (1996) 22 EHRR 1, where it indicated that if the United Kingdom was proposing a power to detain juveniles convicted of murder for life with no possibility of review, then that could be a breach of Article 3 . 
to petition the courts if they felt that the original reasons for their justification no longer held good. ${ }^{40}$ This view was further endorsed in $T$ and $V \mathrm{v}$ United Kingdom where the Court also ruled that the Home Secretary's power to fix an initial tariff of how long a juvenile would spend in jail amounted to a sentencing exercise which, according to Article 6(1), could only be carried out by an independent and impartial tribunal. ${ }^{41}$

In each of these decisions one can see a discomfort, which also appears in the Court's mental health jurisprudence, with the idea that politicians or administrators can decide on deprivations of liberty, beyond the control of judicial authorities. The Convention scheme, especially the structure of Article 5, quite clearly reflects an objective of a separation of powers where questions relating to the removal of a person's liberty belong to the judicial rather than the administrative sphere. They also reflect a European consensus which has witnessed a move away from the use of indeterminate sentences in the direction either of sentences being initially fixed by the courts or with a significant level of judicial oversight of their execution. ${ }^{42}$ Once again the Strasbourg court decisions have had a significant impact on prison law and practice in the United Kingdom, leading to legislative reform in relation to both discretionary lifers and young prisoners, which have substantially reduced the discretionary power of the Home Secretary in relation to both.

However discretionary lifers and HMP prisoners make up less than $20 \%$ of the more than 3000 lifers currently imprisoned in the United Kingdom. The rest are "mandatory" lifers who receive an automatic life sentence on conviction for murder. Life, though, rarely means life and most of these prisoners are released after spending an average of 12-14 years in prison. Before their release, however, they may experience significant periods of uncertainty and a sense of injustice when their applications for release are refused, especially if they discover that others with comparable records are being released. There is considerable concern that politicians, deprived of the use of the death penalty to communicate to the public their attitudes to crime, now use decisions about when to release lifers as a substitute. Overall the system has been widely criticised as arbitrary and capricious. ${ }^{43}$ Domestic courts in the United Kingdom have offered some redress, especially with regard to injecting transparency requirements into the initial tariff setting exercise $^{44}$, but have hitherto lacked the capacity to challenge the central fact of administrative discretion.

The Strasbourg court had the opportunity to take this step when it was faced with the Wynne case in $1994{ }^{45}$ However, despite the fact that even Home Office practice essentially treated mandatory and discretionary lifers in the same way (both had an initial tariff set by the Home Secretary, with a

40 (1996) 22 EHRR 1.

41 Unreported 16 December 1999.

42 See D. Van Zyl Smit "Is Life Imprisonment Unconstitutional?: The German Experience" [1992] Public Law 263.

43 See, for example, Justice Sentenced to Life (1996).

44 Notably in $R$ v Secretary of State, ex parte Doody [1994] 1 AC 531 and $R$ v Secretary of State, ex parte Pierson [1997] 3 ALL ER 577.

45 Wynne v United Kingdom (1994) 19 EHRR 353. 
reference to the Parole Board on its expiry to determine whether the prisoner still posed a significant risk if released) the Court accepted the government's arguments that the two sentences were conceptually different. The Wynne court endorsed the view that a prisoner sentenced to life essentially forfeits her liberty to the state, hence that the whole of her sentence is determined at the initial moment of conviction, rather than by subsequent decisions on tariff or risk. Any decisions to release a prisoner before the end of their life are thus effectively the exercise of a prerogative of mercy. As a result the United Kingdom's lifer release system, which vests significant discretionary power in the hands of the Home Secretary, was held to comply with Article 5. The decision seems difficult to reconcile with cases such as Thynne or $T$ and $V$ and provokes some concern as to whether the Court in the end drew back from imposing too great a burden on the state in the exercise of powers central to traditional state functions. This is a concern which also finds resonance in the immigration and asylum context, which we consider next.

\section{IMMIGRANTS AND ASYLUM SEEKERS}

The obvious point to be made about human rights is that they refer to personhood and not citizenship. They are human rights after all. In other words, human rights are not confined to those possessing the citizenship of a particular state. In simple and attractive logic you possess rights because of your status as a human being only. This is the normative basis upon which much human rights law has been constructed. This ideal is not matched by empirical reality. As we know, status often determines entitlement. The treatment that you can expect to receive is determined, to a significant extent, by who you are. Membership and status within political communities has the major impact on the nature of a person's life. Although the abstract, naked and disengaged person of human rights discourse is nowhere to be found (we are all of course situated selves) the ideal remains a powerful one. ${ }^{46}$ And it is this ideal which forms the normative basis for the defence of immigrants, asylum seekers and refugees. It has become increasingly important in the last decade, as European states have adopted uniformly repressive approaches to immigration and asylum. In practice, the protection of immigrants and asylum seekers is frequently cited as the reason why human rights matter. This is fair, but as the analysis above made clear this cannot become an excuse for unreflective approaches to this area.

In law states have the right to admit and exclude non-citizens. This is a basic element of state sovereignty. The fact shapes the approach of national and international courts and tribunals to immigration and asylum law. Despite all the arguments about postnationalism, most states still view the regulation of migration as a core function of government. This right of states is now, however, subject to rules of law which grant rights to the individual and not the state. The rise of human rights law has led to some questioning of the traditional view of sovereignty. It has evidently had an impact. Although the right to seek asylum, to be found in Article 14 of the Universal Declaration of Human Rights 1948, has not been translated into a binding international Convention, there are other human rights guarantees which

${ }^{46}$ See C. Harvey "Dissident Voices: Refugees, Human Rights and Asylum in Europe" (2000) 9 Social \& Legal Studies 367. 
constrain the state in this area. Article 1 of the European Convention reflects the human rights ideal:

"The High Contracting Parties shall secure to everyone within their jurisdiction the rights and freedoms defined in Section I of this Convention".

The rights apply to everyone within the jurisdiction of the state. While states retain the right to admit persons they must do this within the context of guaranteed Convention rights. On this physical presence is enough to be protected by the Convention. This is not true of all rights. For example, the right to free movement applies to everyone lawfully within the state, ${ }^{47}$ and separate provision is made for nationals and aliens on the prohibition of expulsion. ${ }^{48}$ It is difficult to make a general statement about the precise role of the Court in this context. This is because of the incrementalism noted previously. It will steadily explore the boundaries of Convention rights while demonstrating a consciousness of limits. In expulsion cases this is evident in the willingness to embrace the protection of asylum seekers (even though no direct reference to this group can be found in the Convention) while at the same time displaying an awareness of national asylum systems. The Court has demonstrated that the Convention system should not become a surrogate for national level decision-making on asylum. There are, however, clear gaps in refugee law which are covered in the European Convention; thus it can offer protection not guaranteed in existing refugee law. It would therefore seem to be a relevant tool in the service of refugee protection. Goodwin-Gill has, however, noted that although it would seem to have potential, the reality is that there is a substantial distance between Article 3 and refugee protection. ${ }^{49}$ The Court has repeatedly taken a cautious approach in this area, even though willing to expound general principles which at least in theory apply to refugees.

The cases examined here are simply illustrative examples of the approach the Court has taken to the areas of immigration and asylum. The general context must be kept in view. In the last decade many member states of the Council of Europe have embarked upon policies of restriction against asylum seekers in particular. ${ }^{\text {so }}$ It is within the context of this more exclusionary approach that the assessment of the Court must be based.

\section{Detention}

A point of departure for any examination of detention is that those who seek asylum are not criminals. Asylum is a valid way to seek to enter a state such as Ireland or the UK. Detention is part of the general trend of restriction and deterrence in the member states of the Council of Europe and the detention of asylum seekers is a widespread practice in Europe generally. ${ }^{51}$ The plight

47 Article 2(1), Fourth Protocol.

48 The expulsion of nationals is prohibited (Article 3 Protocol 4). The collective expulsion of aliens is prohibited (Article 4 Protocol 4) and there are procedural safeguards relating to the expulsion of aliens (Article 1 Protocol 6).

so See C. Harvey Seeking Asylum in the UK: Problems and Prospects (2000) ch. 3.

51 See generally J. Hughes and F. Liebaut (eds) Detention of Asylum Seekers in Europe: Analysis and Perspectives (1998). 
of detained asylum seekers has attracted the attention of the ECPT, as well as the European Commission and Court of Human Rights. It is a problematic aspect of national asylum policy which has clear human rights implications. In Amuur v France the applicants were detained at the international zone in the airport and at a hotel nearby. ${ }^{52}$ Their entry into France was refused and they were eventually deported to Syria. They were detained for 20 days prior to deportation. In that period they had access to legal advice for 15 days and the detention was not reviewed by the national court for 17 days. The applicants argued that their rights under Article 5(1) had been violated. In assessing whether there was a deprivation of liberty the Court acknowledged that there was a difference between being held in a detention centre and in the international zone. It noted that such confinement would be acceptable if accompanied by appropriate safeguards and if carried out for the purpose of preventing unlawful immigration. ${ }^{53}$ This had, however, to comply with the 1951 Convention relating to the Status of Refugee. ${ }^{54}$ In particular:

"States' legitimate concern to foil the increasingly frequent
attempts to get round immigration restrictions must not deprive
asylum seekers of the protection afforded by these
Conventions."

The reference to "these Conventions" is noteworthy because this refers to the 1951 Convention also. The Court took into account the fact that the applicants were asylum seekers and had not committed a criminal offence.

On review by the courts it stated:

"Although by the force of circumstances the decision to order holding must necessarily be taken by the administrative or police authorities, its prolongation requires speedy review by the courts, the traditional guardians of personal liberties. Above all, such confinement must not deprive the asylum seeker of the right to gain effective access to the procedure for determining refugee status." 56

There are two points to note about this. First, the Court clearly attached importance to speedy review, and second, it also moved beyond that to include the right to effective access to a refugee status determination procedure. The fact that the applicants were deported to Syria without having a decision taken on their claims to refugee status was a factor in the conclusion reached by the Court. ${ }^{57}$ This is further evidenced in the judgment by reference to the delay in access to legal and social assistance. ${ }^{58}$ When contact with a lawyer was established the national court made an interim order which described the deprivation of liberty as arbitrary. ${ }^{59}$ This was only after the applicants had been deported. 
One argument advanced by the government, that found favour with the Commission, was that the applicants were free to leave the international zone at any time. Although closed on the French side it was open to the outside world. The Court rejected this argument:

"The mere fact that it is possible for asylum seekers to leave voluntarily the country where they wish to take refuge cannot exclude a restriction on liberty, the right to leave any country, including one's own, being guaranteed, moreover, by Protocol No. 4 to the Convention. Furthermore, this possibility becomes theoretical if no other country offering protection comparable to the protection they expect to find in the country where they are seeking asylum is inclined or prepared to take them in." 60

The Court held that Article 5(1) was applicable as holding in the international zone was equivalent to a deprivation of liberty. ${ }^{61}$

As is well known, the Court looks not simply to the existence of national law but to its quality. It must be compatible with the Court's autonomously defined concept of the rule of law. This concept includes the requirement of sufficient accessibility and precision. The Court stressed again the particular importance of this in the case of a "foreign asylum seeker".62

"These characteristics are of fundamental importance with regard to asylum seekers at airports, particularly in view of the need to reconcile the protection of fundamental rights with the requirements of States' immigration policies."

The applicants argued that they had been in a legal vacuum because, according to the applicable French law, they were not in France while being held in the international zone. The Court rejected the argument that the international zone had extraterritorial status. The only document which dealt specifically with the holding of aliens at the material time was an unpublished circular issued in 1990. The Court held that there was not adequate legal protection in French domestic law against arbitrary interferences with the Convention ${ }^{64}$ At the material time domestic laws did not provide for review by the courts of holding in the international zone:

"They did not provide for legal, humanitarian and social assistance, nor did they lay down procedures and time-limits for access to such assistance so that asylum seekers like the applicants could take the necessary steps." 65

Amuur is an important judgment and its implications must be understood. There are several points of interest. The Court attached particular significance to the plight of asylum seekers. It took their particular problems into account, both in its assessment of the applicability of Article 5(1), and 
its substantive judgment on compatibility. This is reflected in its focus on the right to effective access to a determination process. The right is a vital aspect of refugee protection and one which the Court recognised as significant. The Court acknowledged how states might try to avoid their Convention obligations by creating lawless spaces. It was alive to the problem and addressed it in this judgment.

\section{Human Rights Law and Non-Refoulement}

The most important guarantee for the asylum seeker is that she will not be returned to an unsafe state. ${ }^{66}$ This is reflected in the fundamental status of the norm of non-refoulement.$^{67}$ The Court has developed Article 3 to include a prohibition on return in extradition and expulsion cases, where there is a sufficiently serious risk of ill-treatment in the state of origin. The judgment of the Court in Soering v UK (an extradition case) was significant because of the way it was prepared to stretch traditional notions of international responsibility. ${ }^{68}$ In Cruz Varas $\vee$ Sweden the Court extended this to expulsion. ${ }^{69}$ In practice a number of Article 3 expulsion cases are settled before a final judgment of the Court. This demonstrates that the Convention can have a practical impact regardless of whether the case ever reaches the final stages of the process.

Once the Court had extended Article 3 it was aware of the problems that could result from an overly expansive approach. The issues were raised and addressed in Vilvarajah $\mathrm{v} U K^{30}$ The five applicants in the case had all been refused asylum in the UK and were returned to Sri Lanka. They successfully appealed against their refusal of leave to enter from Sri Lanka (an appeal on the merits was only available once they had left the UK). The applicants argued that the refusal of asylum by the UK constituted a violation of Articles 3 and 13 of the Convention. In these cases the Court has to determine whether at the material time substantial grounds had been shown for believing that there was a real risk of treatment contrary to Article 3 upon return. As the applicants had been returned, the Court focused on what the foreseeable consequences were at the material time. The Court noted the general improvement in the human rights situation in the relevant parts of Sri Lanka. The initiation of a repatriation scheme by the UNHCR was taken as a strong indication of improvement. In addition, the Court did not believe that the personal situation of the applicant "was any worse than the generality of other members of the Tamil community or other young male Tamils who are returning to their country" ${ }^{71}$ It was noted that there was a possibility that they might be detained and ill-treated:

${ }^{66}$ Most cases have revolved around expulsion, but there have been admission cases where the Convention has been used: see East African Asians v UK (1981) 3 EHRR 76; Lalljee v UK (1986) 8 EHRR 45; Abdulaziz, Cabales and Balkandali v $U K$ (1985) 7 EHRR 471 .

67 See H. Lambert "Protection against refoulement in Europe: Human Rights Law comes to the Rescue" (1999) 48 ICLQ 515.

68 (1989) 11 EHRR 439.

69 (1992) 14 EHRR 1. For consideration of the applicability of the principle to a safe third country case see T.I. v UK, Decision of 3 March 2000.

70 (1992) 14 EHRR 1.

71 Para 111 
"A mere possibility of ill-treatment, however, in such circumstances, is not in itself sufficient to give rise to a breach of Article 3."72

Although the second, third and fourth applicants claimed to have suffered illtreatment when returned, the Court stated that "there were no special distinguishing features in their cases that could or ought to have enabled the Secretary of State to foresee that they would be treated in this way". ${ }^{73}$ The Court also lent weight to the experience of the UK in dealing with asylum cases from Sri Lanka. ${ }^{74}$ The Court held that there had not been a violation of Article 3.

The applicants also argued that they had no effective remedy in the UK. Judicial review in this context, did not, they argued, constitute an effective remedy ${ }^{75}$ While the Court acknowledged the limitations of judicial review, it held that there was in judicial review proceedings an effective measure of control in asylum cases. This generous assessment of judicial review can be contrasted with the dissent of Judge Walsh, joined by Judge Russo. He noted that this case could be distinguished from Soering because the facts were in dispute. As he stated, judicial review did not function to resolve issues of disputed facts, and in English law its purpose was principally to control procedures, but not offer a remedy on the merits of the case. It is evident that the Court is prepared to pay due regard to national asylum systems. Three aspects of this case stand out. First, the Court advanced a highly personalised approach to the Article 3 claim, based on factors which distinguished them from the general population. Second, the Court took into account the experience of the UK authorities in these types of asylum cases. And finally, it adopted a very generous interpretation of the effectiveness of judicial review. While there have been clear advances in judicial review, it still remains a weak remedy for the asylum seeker.

Some applicants have been successful before the Court. In Chahal $\mathrm{v} U K$ the applicant won his case. ${ }^{76}$ He was a Sikh political activist who had been detained in the UK pending his deportation to India for national security reasons. His claim to asylum was rejected. He successfully argued that his return would violate Article 3 , and that the denial of the opportunity to have the lawfulness of his detention challenged in a national court violated Article 5(4). Key to his success on Article 5(4) were the restrictions imposed on national courts by the security aspects of the case and the inadequacy of the existing procedures. The national court was effectively unable to review the decision to keep him in detention for security reasons. The advisory panel that did exist was inadequate for a variety of reasons, including that he had no access to legal representation. As noted, the case is exceptional. The applicant was a high profile political activist who had been detained for six years. The inadequacy of the UK's arrangements in these cases was well known and particularly serious. While the facts were exceptional, it still

Para 111

73 Ibid.

74 Para 114.

75 The Court in Soering $v$ UK had held that judicial review was an effective remedy.

76 (1996) 23 EHRR 413. 
demonstrates that the Convention system can be used productively by applicants.

Another example of the exceptional use of Article 3 is $D \mathrm{v} U K{ }^{77}$ The applicant had been convicted for drug trafficking offences while seeking to enter the UK. After his release he was sent to an immigration detention centre to await deportation to St Kitts. However, while in prison the applicant was diagnosed as HIV positive and as suffering from AIDS. The applicant argued successfully that his return would violate Article 3 . At the time of the proposed removal the applicant was seriously ill, he had no close relatives in St Kitts and would have no financial resources available to him. The withdrawal of the medical services in the UK would hasten his death and equivalent services were not available in St Kitts. The Court took account of the fact that he had come to rely on the medical services available in the United Kingdom:

"Although it cannot be said that the conditions which would confront him in the receiving country are themselves a breach of the standards of Article 3, his removal would expose him to a real risk of dying under most distressing conditions and would thus amount to inhuman treatment." ${ }^{\text {" }}$

The Court noted that these were exceptional circumstances. ${ }^{79}$ In order to reinforce this point it stated:
"Against this background the Court emphasises that aliens who have served their prison sentences and are subject to expulsion cannot in principle claim any entitlement to remain on the territory of a Contracting State in order to continue to benefit from medical, social or other forms of assistance provided by the expelling State during their stay in prison. However, in the very exceptional circumstances of this case and given the compelling humanitarian considerations at stake, it must be concluded that the implementation of the decision to remove the applicant would be a violation of Article 3." 80

As with Chahal v UK this was clearly an exceptional case. These cases illustrate in practice a certain dynamism in approach but also a strong element of caution. On Article 3 there is an awareness of boundaries and limits to this right. Although the Court is prepared to extend its reach, it does so incrementally.

\section{Migrants, Criminality and the Right to Private and Family Life}

Just as the state retains the right to admit persons onto its territory, it also has the right to expel or remove a non-national. This right of the state is now subject to an extensive range of human rights guarantees. 
The Article 3 jurisprudence has the advantage of coherence. It is now well established who is protected by it in the immigration and asylum areas. This may be because the issue of balance is not a factor in this jurisprudence. This is not the case with Article $8^{81}$ The case law on this provision lacks coherence and the reasoning is highly casuistic. In immigration and asylum cases the issue is mainly whether deportation is "necessary in a democratic society". The Court has struggled to provide a coherent approach to the balancing exercise that is required. While this may result in justice in the individual case, it does not assist in the task of facilitating effective national level protection. This is problematic at a time of general restriction against third country nationals in Europe.

The Article 8 cases can be particularly troubling because the applicants tend to have established themselves in the state for some time. ${ }^{82}$ The use of deportation as a response to criminality by integrated immigrants, after they have been subjected to punishment through national criminal law, is problematic. It is a legal and policy option, however, which many states in Europe wish to retain. A few cases will illustrate the points made here. In Moustaquim $\mathrm{v}$ Belgium the applicant had lived in Belgium from the age of one and after the commission of several offences was deported after having served his sentence. ${ }^{83}$ His deportation was later suspended. All his close relatives lived in Belgium and he had resided there for about twenty years. The applicant argued that his deportation violated his right to private and family life under Article 8(1). These cases typically hinge on an assessment of whether deportation is "necessary in a democratic society". In this instance the Court held that the means employed were disproportionate to the legitimate aims sought. Materials factors included the long period between the commission of the offences and the deportation order, the strength of his family ties and the fact that he had returned to Morocco only twice. This case can be contrasted with Boughanemi $\mathrm{v}$ France where the Court held that there was no violation of Article $8{ }^{84}$ The applicant had lived in France for twenty years and was deported in 1988, following his conviction for several criminal offences. He returned illegally and had a child with a French woman, but was deported again in October 1994. His close family all resided legally in France. He claimed that the deportation violated his rights under Article 8. Although the facts were similar to Moustaquim v Belgium and other cases ${ }^{85}$ the Court felt confident that this case could be distinguished. Two factors appear to have counted heavily against the applicant. First, he had retained his Tunisian nationality, and second, his offences were judged to be particularly serious. Judge Martens, in his dissent, stressed the problems with the way the Court chose to address this issue. The Court started, he stated, from the premise that the Convention did

81 See H. Lambert "The European Court of Human Rights and the Right of Refugees and Other Persons in Need of Protection to Family Reunion" (1999) 11 IJRL 427; H. Storey "The Right to Family Life and Immigration Case Law at Strasbourg" (1990) 39 ICLQ 329. See also C. Warbrick "The Structure of Article 8" [1998] EHRLR 32.

85 See Beldjoudi v France (1992) 14 EHRR 801 and Nasri v France (1996) 21 EHRR 458. 
not protect integrated aliens from expulsion. This focused attention on the applicant's right to family life. He noted two problems with this approach. First, not every integrated alien would necessarily have a family life, and second, it led to a lack of legal certainty. He described the approach as a lottery which was an embarrassment to the Court. He made a number of suggestions, including that the expulsion of an integrated alien should constitute a violation of Article 3 . In addition, he argued that the Court should accept that expulsion of an integrated alien, as a rule, constituted a lack of respect for private life, but would exceptionally be justified in cases of conviction for very serious crimes. He cited serious crimes against the state, political or religious terrorism and holding a leading position in a drug trafficking organisation. This position, if accepted, would result in greater legal certainty and would shift the emphasis much more securely on to the rights of the individual. The majority of the Court has not been persuaded, however, to alter its position.

There are clearly complex issues involved in the deportation cases decided under Article 8 and other cases could be mentioned here. The Court must balance public order considerations against the fact that the individual will suffer considerably during and after the deportation process. In situations where an individual has been living in a state for twenty years or more, and where her close family resides legally, this makes matters worse. The difficulty at present is that it is not clear on what precise basis the balancing exercise is being conducted. The seriousness of the offence plays a part, as does the individual's links with the receiving state. It is not clear that the principles which underpin the Court's reasoning in these cases is sound. There is room for more to be done to protect the rights of immigrants in these cases. This is particularly if the primary focus of the jurisprudence is to ensure effective protection at the national level.

\section{CONCLUSION}

Asylum seekers, immigrants and prisoners have sometimes been seen as beyond the reach of civil rights law. In both theory and practice they can fall outside the cosy world of democratic citizenship. Asylum seekers and immigrants are not citizens and prisoners have, historically, been treated as forfeiting their civil status by the fact of imprisonment. The European Court has been prepared to bring both groups within its regime of rights protection. In doing so it has rejected the idea that the treatment of any group in society is beyond the scope of the law and has curbed the most brutal forms of disregard of these groups. However there remains the feeling that it has proceeded cautiously. In the Article 3 conditions jurisprudence relating to prisoners, or the Article 8 family jurisprudence on immigrants, there is a sense of the Strasbourg institutions not wanting to go too far, perhaps because these areas involve core state functions. The Court, in particular, has stressed the importance of national level protection. Indeed the Court's jurisprudence in these areas has had an important impact at the national level. In relation to prisoners we note that many of the cases have resulted in significant change at the national level. On immigration and asylum the jurisprudence has clearly impacted on the development of the concept of non-refoulement within the member states of the Council of Europe. It has also resulted in changes in national practice in this area too. There is a mixture of doctrinal advancement and judicial caution. On asylum, for 
example, the Court has no intention of becoming a surrogate for the failures of national asylum systems. We argue that a more assertive approach can be taken, and fully justified, within the Court's own self-understanding of its role. These are groups which tend to be marginalised and excluded in democratic polities. The Court could assist in attacking this process by developing a coherent and robust approach to the defence of human rights in these areas. In this article we have attempted to show what the Court has achieved and where improvements might be made. We will see how the Court progresses in the next fifty years. 